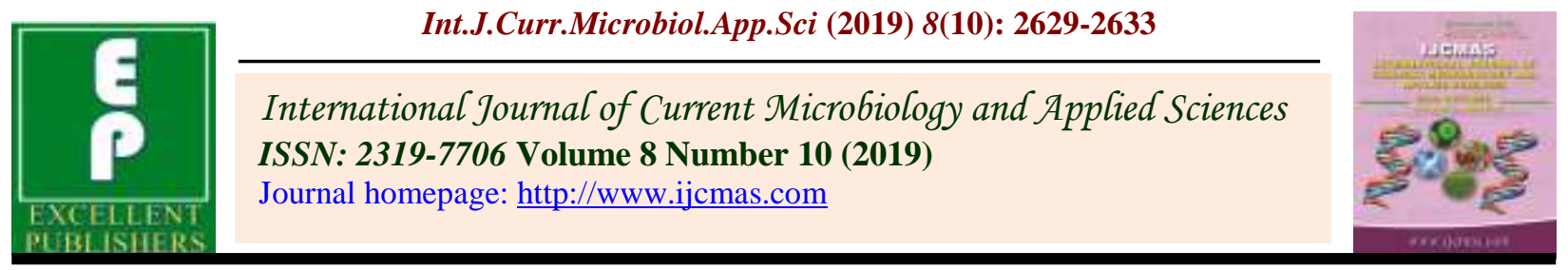

Original Research Article

https://doi.org/10.20546/ijcmas.2019.810.303

\title{
Effect of Integrated Weed Management on Yield, Yield Attributes and Economics of Pearl Millet [Pennisetum glaucum (L.) R. Br. Emend stuntz]
}

\author{
Yalamati Sree Ram Kumar, Rabindra Kumar*, Yasin Abrar Baba and M. Samruthi
}

Department of Agronomy, Suresh Gyan Vihar University, Jaipu, Rajasthan-302017, India

*Corresponding author

\begin{tabular}{|l|}
\hline Keyw or d s \\
Pearl millet, \\
Alachlor, Atrazine, \\
Oxyfluorfen, Hand \\
weeding
\end{tabular}

A B S T R A C T

A field experiment entitled "Effect of integrated Weed management on pearl millet [Pennisetum glaucum (L.) R. Br. emend Stuntz]"was conducted at Agricultural farm, Suresh GyanVihar University, Jagatpura, Jaipur, Rajasthan in Kharif 2018. The experiment consisted of nine weed management treatments involving three pre-emergence herbicides (Alachlor, Atrazine and Oxyflourfen) in randomized block design with three replications. Among the treatments, 2 Hand weedings (HW) at 20 and $40 \mathrm{DAS}\left(\mathrm{T}_{2}\right)$ attained higher grain, stover and biological yield $\left(1987,4935\right.$ and $\left.6922 \mathrm{~kg} \mathrm{ha}^{-1}\right)$ over other treatments. In case of earhead length and harvest index, Atrazine @ $750 \mathrm{~g} \mathrm{ha}^{-1}(\mathrm{PE})+1 \mathrm{HW}$ at 20 DAS $\left(\mathrm{T}_{6}\right)$ recorded higher with $8.48 \mathrm{~g}$ and $28.77 \%$ respectively. In case of economics, $2 \mathrm{HW}$ at 20 and 40 DAS $\left(\mathrm{T}_{2}\right)$ attained highest gross returns $\left(₹ 49064 \mathrm{ha}^{-1}\right)$ and Atrazine @ $750 \mathrm{~g} \mathrm{ha}^{-1}(\mathrm{PE})+1 \mathrm{HW}$ at 20 DAS $\left(\mathrm{T}_{6}\right)$ attained higher net returns and BCR with $(₹ 23332$ $\mathrm{ha}^{-1}$ ) and (1.91) respectively. Among all the yield attributes i.e. ear head length, test weight, grain yield, stover yield, biological yield and harvest index $(20.5,6.10,863,2836$, 3698 and 23.33, respectively) attained the lowest values and economics i.e. net returns and BCR (2717 and 1.12, respectively) attained the lowest values.

\section{Introduction}

Pearl millet [Pennisetum glaucum (L.) R.Br. emend Stuntz] is one of the important cereal crop of arid and semi-arid climatic conditions. Cultivation of pearl millet is mainly confined to the Southern Asia (India, Pakistan, Nepal, Bhutan and Afghanistan) and Africa (Nigeria, Niger, Mali, Tanzania, Sudan and Senegal). India is the largest producer of pearl millet having $7.47 \mathrm{~m}$ ha area with annual production of 9.86 million tonnes grain and productivity of $1319 \mathrm{~kg} \mathrm{ha}^{-1}$ (Anonymous, 2018). As pearl millet is grown predominantly in warm rainy season, weeds of different kinds deprive the crop of vital nutrients, moisture, light and space. Das and Yaduraju (1995) have reported $72 \%$ or more yield loss in pearl millet due to its initial slow growth. It picks up growth, start tillering and increase in height after 25-30 days after sowing (DAS) and become more competitive against weeds. Weed management has been always a basic, indispensable integral part of agriculture. Manual weeding is a common practice adopted for weed control throughout the crop season is a labour and 
cost-intensive affair. Therefore, integrated approach for weed management using chemical and non chemical methods have been in practice for achieving better management of weeds in field.

\section{Materials and Methods}

\section{Experimental details}

A field experiment was conducted during kharif, 2018 at Suresh Gyan Vihar University, Agricultural farm, Jagatpura, Jaipur, Rajasthan. The soil was sandy clay loam in texture, low in organic carbon $(0.15 \%)$, available $\mathrm{N}\left(0.40 \mathrm{~kg} \mathrm{ha} \mathrm{ha}^{-1}\right)$, medium in available P (42 $\mathrm{kg} \mathrm{ha}^{-1}$ ) and available K (290 $\mathrm{kg} \mathrm{ha}{ }^{-1}$ ) with $\mathrm{pH}$ 8.48. Nine treatments of weed control were evaluated in randomized block design replicated thrice with hybrid RHB- 173. The recommended dose of $60 \mathrm{~kg}$ $\mathrm{N}, 30 \mathrm{~kg} \mathrm{P}_{2} \mathrm{O}_{5}$ and $0 \mathrm{~kg} \mathrm{~K}_{2} \mathrm{O} \mathrm{ha}^{-1}$ was applied. Entire quantity of nitrogen and phosphorous were applied as basal dose through urea and single super phosphate, respectively. The seeds were sown with a spacing of $45 \times 15$ $\mathrm{cm}$. Thinning and gap filling were done at 15 DAS.

\section{Treatment details}

The treatments consisted of Control $\left(\mathrm{T}_{0}\right), 1$ HW at 20 DAS $\left(\mathrm{T}_{1}\right), 2 \mathrm{HW}$ at 20 and 40 DAS $\left(\mathrm{T}_{2}\right)$, Alachlor @ $1000 \mathrm{~g} \mathrm{ha}^{-1}(\mathrm{PE})\left(\mathrm{T}_{3}\right)$, Alachlor@1000 $\mathrm{g} \mathrm{ha}^{-1}+1 \mathrm{HW}$ at 20 DAS $\left(\mathrm{T}_{4}\right)$,Atrazine @ $750 \mathrm{~g} \mathrm{ha}^{-1}(\mathrm{PE})\left(\mathrm{T}_{5}\right)$, Atrazine (a) $750 \mathrm{~g} \mathrm{ha}^{-1}+1 \mathrm{HW}$ at $20 \mathrm{DAS}\left(\mathrm{T}_{6}\right)$, Oxyfluorfen@150 $\mathrm{g} \mathrm{ha}^{-1}$ (PE) $\left(\mathrm{T}_{7}\right)$ and Oxyfluorfen@150 $\mathrm{g} \mathrm{ha}^{-1}+1 \mathrm{HW}$ at 20 DAS $\left(\mathrm{T}_{8}\right)$. Pre-emergence herbicides were applied 1 day after sowing (DAS), uniformly by using spray fluid@800 L ha ${ }^{-1}$ with the help of knapsack sprayer. Hand weedings were carried out in the respective treatments at 20 and 40 DAS.

\section{Statistical analysis}

The observations on yield and yield attributes were recorded at harvest. The statistical analyses were done by using OP STAT.

\section{Results and Discussion}

\section{Weed flora}

Weed survey during the experimentation showed that the crop was heavily infested by weeds immediately after the emergence of the crop. The prominent annual dicot weed species noted to invade the crop were Digera arvensis, Amaranthus viridis, Amaranthus spinosus, Phyllanthus niruri, Trianthema portulacastrum etc. Whereas, Cyperus rotundus, Dactyloctenium aegypticum, Digitaria sanguanalis, Cenchrus biflorus and Cynodon dactylon were the major grassy and sedge species found to invade the crop.

\section{Yield and yield attributes}

Yield attributes showed a varied difference among the parameters. $2 \mathrm{HW}$ at 20 and 40 DAS $\left(\mathrm{T}_{2}\right)$ recorded the highest yield attributes i.e. grain, stover, biological yield and test weight of pearl millet, which were statistically similar to pre-emergence application of atrazine @ $750 \mathrm{~g} \mathrm{ha}^{-1}(\mathrm{PE})+1 \mathrm{HW}$ at 20 $\mathrm{DAS}\left(\mathrm{T}_{6}\right)$. Other parameters i.e.Length of earhead and harvest index recorded highest in $\left(\mathrm{T}_{6}\right)$ atrazine @ $750 \mathrm{~g} \mathrm{ha}^{-1}(\mathrm{PE})+1 \mathrm{HW}$ at 20 DAS, which was statistically similar to $2 \mathrm{HW}$ at 20 and 40 DAS $\left(\mathrm{T}_{2}\right)$. The treatments associated with pre-emergence application of oxyfluorfen@150 $\mathrm{g} \mathrm{ha}^{-1}$ resulted in reduced yield attributes and yield in pearl

\section{Economics}

The treatment $\left(\mathrm{T}_{2}\right) \mathrm{HW}$ twice at 20 and 40 DAS resulted in the highest gross returns, which was in parity with treatment $\left(\mathrm{T}_{6}\right)$ 
atrazine @ $750 \mathrm{~g} \mathrm{ha}^{-1}(\mathrm{PE})+1 \mathrm{HW}$ at 20 DAS. However, the treatment $\mathrm{T}_{6}$ recorded the highest net returns and benefit-cost ratio (Table 2). The treatment with alachlor @ $1000 \mathrm{~g} \mathrm{ha}^{-1}(\mathrm{PE})$ and alachlor @ $1000 \mathrm{~g} \mathrm{ha}^{-}$ ${ }^{1}(\mathrm{PE})+1 \mathrm{HW}$ at $20 \mathrm{DAS}$ recorded lesser gross, net returns and benefit-cost ratio due to lower yield level and higher cost of cultivation. The lowest gross, net returns and benefit-cost ratio were observed in control $\left(\mathrm{T}_{0}\right)$ due to the uncontrolled growth of weeds which resulted in lowest yield associated with it.

Table.1 Effect of integrated weed management practices on yield and yield attributes of pearl millet at harvest

\begin{tabular}{|c|c|c|c|c|c|c|}
\hline Treatments & $\begin{array}{l}\text { Earhead } \\
\text { length } \\
\text { (cm) }\end{array}$ & $\begin{array}{c}\text { Test } \\
\text { weight } \\
\text { (gm) }\end{array}$ & $\begin{array}{c}\text { Grain } \\
\text { yield } \\
\left(\mathrm{kg} \mathrm{ha}^{-1}\right)\end{array}$ & $\begin{array}{c}\text { Stover } \\
\text { yield } \\
\left(\mathrm{kg} \mathrm{ha}^{-1}\right)\end{array}$ & $\begin{array}{c}\text { Biological } \\
\text { yield } \\
\left(\mathbf{k g ~ h a}^{-1}\right)\end{array}$ & $\begin{array}{l}\text { Harvest } \\
\text { index }\end{array}$ \\
\hline $\mathbf{T}_{0^{-}}$Control & 20.5 & 6.10 & 863 & 2,836 & 3,698 & 23.33 \\
\hline $\mathrm{T}_{1}-1 \mathrm{HW}$ at $20 \mathrm{DAS}$ & 29.2 & 7.93 & 1,526 & 3,856 & 5,378 & 28.37 \\
\hline $\mathrm{T}_{2}-2 \mathrm{HW}$ at 20 and 40 DAS & 31.0 & 8.43 & 1,987 & 4,935 & 6,922 & 28.70 \\
\hline $\begin{array}{l}\mathrm{T}_{3} \text {-Alachlor @ } 1000 \mathrm{~g} \mathrm{ha}^{-1} \\
\text { (PE) }\end{array}$ & 25.9 & 7.16 & 1,036 & 3,212 & 4,248 & 24.38 \\
\hline $\begin{array}{l}\mathrm{T}_{4} \text {-Alachlor @ } 1000 \mathrm{~g} \mathrm{ha}^{-1} \\
(\mathrm{PE})+1 \text { HW at } 20 \mathrm{DAS}\end{array}$ & 26.4 & 7.36 & 1,339 & 3,516 & 4,855 & 27.57 \\
\hline $\begin{array}{l}\text { T }_{5^{-}} \text {Atrazine @ } 750 \mathrm{~g} \mathrm{ha}^{-1} \\
(\mathrm{PE})\end{array}$ & 28.6 & 8.26 & 1,641 & 4,325 & 5,966 & 27.50 \\
\hline $\begin{array}{l}\mathrm{T}_{6} \text { - Atrazine @ } 750 \mathrm{~g} \mathrm{ha}^{-1} \\
(\mathrm{PE})+1 \mathrm{HW} \text { at } 20 \mathrm{DAS}\end{array}$ & 32.4 & 8.36 & 1,976 & 4,898 & 6,874 & 28.77 \\
\hline $\begin{array}{l}\mathrm{T}_{7}-\text { Oxyfluorfen @ } 150 \mathrm{~g} \mathrm{ha}^{-} \\
{ }^{-}(\mathrm{PE})\end{array}$ & 23.5 & 7.40 & 1,156 & 3,189 & 4,344 & 26.60 \\
\hline $\begin{array}{l}\mathrm{T}_{8} \text {-Oxyfluorfen @ } 150 \mathrm{~g} \mathrm{ha}^{-} \\
{ }^{-} \text {(PE)+1 HW at } 20 \text { DAS }\end{array}$ & 24.6 & 7.13 & 1,456 & 3,456 & 4,911 & 29.63 \\
\hline $\mathbf{S E}(\mathbf{m}) \pm$ & 1.1 & 0.47 & 70 & 165 & 240 & 1.14 \\
\hline CD at $5 \%$ & 3.4 & NS & 212 & 501 & 726 & NS \\
\hline
\end{tabular}

Table.2 Effect of integrated weed management practices on economics of pearl millet

\begin{tabular}{|c|c|c|c|c|c|c|c|}
\hline \multirow[t]{2}{*}{ Treatments } & \multicolumn{2}{|c|}{ Yield $\left(\mathrm{kg} \mathrm{ha}^{-1}\right)$} & \multicolumn{2}{|c|}{ Return } & \multirow{2}{*}{$\begin{array}{c}\text { Gross } \\
\text { returns }\end{array}$} & \multirow[t]{2}{*}{ Net returns } & \multirow[t]{2}{*}{ BCR } \\
\hline & Grain & Stover & Grain & Stover & & & \\
\hline $\mathbf{T}_{0^{-}}$-Control & 863 & 2836 & 13808 & 9926 & 23734 & 2717 & 1.12 \\
\hline$T_{1}-1 \mathrm{HW}$ at $20 \mathrm{DAS}$ & 1526 & 3856 & 24416 & 13496 & 37912 & 13520 & 1.55 \\
\hline$T_{2}-2 \mathrm{HW}$ at 20 and 40 DAS & 1987 & 4935 & 31792 & 17272 & 49064 & 21297 & 1.76 \\
\hline $\begin{array}{l}T_{3} \text {-Alachlor @ } 1000 \mathrm{~g} \mathbf{h a}^{-1} \\
(\mathrm{PE})\end{array}$ & 1036 & 3212 & 16576 & 11242 & 27818 & 5026 & 1.22 \\
\hline $\begin{array}{l}\mathrm{T}_{4} \text {-Alachlor @ } 1000 \mathrm{~g} \mathrm{ha}^{-1} \\
(\mathrm{PE})+1 \mathrm{HW} \text { at } 20 \mathrm{DAS}\end{array}$ & 1339 & 3516 & 21424 & 12306 & 33730 & 7563 & 1.28 \\
\hline $\mathrm{T}_{5}$-Atrazine @ $750 \mathrm{~g} \mathrm{ha}^{-1}(\mathrm{PE})$ & 1641 & 4325 & 26256 & 15137 & 41393 & 19341 & 1.87 \\
\hline $\begin{array}{l}\mathrm{T}_{6} \text {-Atrazine @ } 750 \mathrm{~g} \mathrm{ha}^{-1}(\mathrm{PE}) \\
+1 \mathrm{HW} \text { at } 20 \text { DAS }\end{array}$ & 1976 & 4898 & 31616 & 17143 & 48759 & 23332 & 1.91 \\
\hline $\begin{array}{l}\mathrm{T}_{7} \text {-Oxyfluorfen @ } 150 \mathrm{~g} \mathrm{ha}^{-1} \\
\text { (PE) }\end{array}$ & 1156 & 3189 & 18496 & 11161 & 29657 & 7785 & 1.35 \\
\hline $\begin{array}{l}\mathrm{T}_{8} \text {-Oxyfluorfen @ } 150 \mathrm{~g} \mathrm{ha}^{-1} \\
(\mathrm{PE})+1 \mathrm{HW} \text { at } 20 \text { DAS }\end{array}$ & 1456 & 3456 & 23296 & 12096 & 35392 & 10145 & 1.40 \\
\hline
\end{tabular}


It is clear from the results that all the IWM treatments evaluated in present study varied widely in their effect on yield attributing characters like length of ear head, test weight, grain, stover and biological yields were found significantly superior in comparison to control treatment. The maximum test weight $(8.43 \mathrm{~g})$ was recorded under the treatment $\mathrm{T}_{2}(2 \mathrm{HW}$ at 20 and 40 DAS). This result might be due to the fact that increased uptake of nutrients due to weed free environment and as a result there was more growth and development and thereby resulted in higher test weight (Singh et al. 2001). The highest ear head length was observed under Atrazine @ $750 \mathrm{~g} \mathrm{ha}^{-1}(\mathrm{PE})+$ $1 \mathrm{HW}$ at $20 \mathrm{DAS}\left(\mathrm{T}_{6}\right)$. Two $\mathrm{HW}$ at 20 and 40 DAS $\left(\mathrm{T}_{2}\right)$ recorded grain and stover yield (1,339 and 3,516 $\mathrm{kg} \mathrm{ha}^{-1}$, respectively) kept the crop almost weed free environment which in turn resulted in significant reduction in competition for nutrients and other growth resources by weeds (Vanaja. 2007), Srividhya et al. (2011), Sandhyarani and Karunasagar (2013) and Sunitha et al. (2011). Furthermore, the most severe competition throughout the crop season due to unrestricted weed growth under Control $\left(\mathrm{T}_{0}\right)$ plots increased the depletion and moisture by weeds, thus adversely affecting the crop growth and ultimately resulted in the lowest yield of crop (Kaur and Singh. 2006), Kiroriwal et al. (2012) and Munde et al. (2013) in pearl millet.

All the integrated weed control treatments provided significantly higher net returns and $\mathrm{B}$ : $\mathrm{C}$ ratio in comparison to control. Atrazine @ $750 \mathrm{~g} \mathrm{ha}^{-1}(\mathrm{PE})+1 \mathrm{HW}$ at $20 \mathrm{DAS}\left(\mathrm{T}_{6}\right)$ treatment fetched the maximum net returns ( $₹$ $23332 \mathrm{ha}^{-1}$ ) with a BCR of 1.91. The higher net returns under superior treatment was the result of higher grain and stover yield due to effective control of weeds. The lowest grain yield achieved under control $\left(\mathrm{T}_{0}\right)$ treatment was eventually reflected in the lowest net returns (₹ $2717 \mathrm{ha}^{-1}$ ) and $\mathrm{B}$ : C ratio (1.12).
Results of the present investigation corroborate with the findings of Arvadiya et al. (2012), Mathukia et al. (2015) and Mishra et al. (2017) in pearl millet.

\section{References}

Anonymous, (2018).Indian Economy Survey, Area, Production and Yield of major crops. Govt of India, Ministry of finance, economic division, New Delhi.

Arvadiya, L. K., Raj, V. C., Patel, T. U. and Arvadiya, M. K. (2012). Influences of plant population and weed management on weed flora and productivity of sweet corn (Zea mays). Indian Journal of Agronomy, 57(2): 162-167.

Das, T. K. and Yaduraju, N.T. (1995).Crop weed competition studies in some kharif crops: 11, nutrient uptake and yield reduction. Annals of Plant Protection Science, 3(2): 95-99.

Kaur, A. and Singh, V.P. (2006). Weed dynamics as influenced by planting methods, mulching and weed control in rainfed hybrid pearl millet (Pennisetum glaucum). Indian Journal of WeedScience, 38(1\&2): 135-136.

Kiroriwal, A., Yadav, R.S. and Kumawat, A. (2012). Weed management in pearl millet based intercropping system. Indian Journal of Weed Science, 44(3): 200-203.

Mathukia, R.K., Mathukia, P.R. and Polara, A.M. (2015). Intercropping and weed management in pearl millet (Pennisetum glaucum) under rainfed condition. Agriculture ScienceDigest, 35(2): 138141.

Mishra, P. S., Ramu Reddi, Y., Subramanyam, D. and Umamahesh, V.(2017).Impact of integrated weed management practices on weed dynamics, growth and yield of Pearl millet [Pennisetum glaucum(L). R. Br. Emend Stuntz] of International journal 
of Agriculture sciences, 9(3): 36773678 .

Munde, S.D., Patel, J.C., Ali, S. and Aghav, V.D. (2013). Weed control study in kharif pearl millet (Pennisetum glaucum). Bioinfolet, 10(2A): 464-468.

Sandhyarani, B. and Karunasagar, G. (2013). Effect of integrated weed management on growth, yield and economics of sweet corn.Agriculture Science Digest. 33(1): 52-55.

Singh, R. K., Chauhan, S. P. S. and Singh, S. (2001). Integrated weed management in pearl millet (Pennisetum typhoides). Indian Journal of Weed Science,33(3\&4): 206-208.

Srividhya, S., Chandrasekhar, K. and
Veeraraghavaiah.(2011). Effect of tillage and herbicide use on weed management in maize (Zea mays L.). Andhra Agriculture Journal, 58(2): 123-125.

Sunitha, N., Maheswara Reddy, P. and Reddy, D. S. (2011). Influence of planting pattern and weed control practices on weed growth, nutritive uptake and productivity of sweet corn. CropResearch.41(1,2\&3): 13-20.

Vanaja, C. H. (2007). Weed management studies in kharif maize. M. Sc. (Agriculture) Thesis submitted to Acharya N. G. Ranga Agricultural University Rajendranagar, Hyderabad.

\section{How to cite this article:}

Yalamati Sree Ram Kumar, Rabindra Kumar, Yasin Abrar Baba and Samruthi, M. 2019. Effect of Integrated Weed Management on Yield, Yield Attributes and Economics of Pearl Millet [Pennisetum glaucum (L.) R. Br. Emend stuntz]. Int.J.Curr.Microbiol.App.Sci. 8(10): 26292633. doi: https://doi.org/10.20546/ijcmas.2019.810.303 